\title{
Feeding habits of the speckled guitarfish Rhinobatos glaucostigma (Elasmobranchii, Batoidea) in the southeastern Gulf of California
}

\section{Hábitos alimentarios de la guitarra punteada Rhinobatos glaucostigma (Elasmobranchii, Batoidea) en el sureste del golfo de California}

\author{
Karina de la Rosa-Meza, Oscar Sosa-Nishizaki*, Horacio de la Cueva-Salcedo \\ Centro de Investigación Científica y de Educación Superior de Ensenada, Carretera Ensenada-Tijuana 3918, \\ Zona Playitas, CP 22860, Ensenada, Baja California, México \\ * Corresponding author. E-mail: ososa@cicese.mx
}

\begin{abstract}
To assess the feeding habits of Rhinobatos glaucostigma (speckled guitarfish), the stomach contents of 176 individuals were examined. Specimens were obtained from the artisanal gillnet fisheries operating off Nayarit, Mexico, in the southeastern region of the Gulf of California, during January-August 2008 and January-May 2009. Relative measures of prey quantities and nonparametric multivariate methods were used to analyze diet differences between sex and maturity stages. The trophic relationship and feeding strategy were determined using Levin's niche amplitude index, the Costello method modified by Amundsen, and Pianka's diet overlap index. The overall diet was dominated by crustaceans, primarily decapods, brachyurans, and cumaceans. Diets were similar between sexes and maturity stages, except between mature females and males where only slight differences were found. Mature females and immature specimens of both sexes showed specialized diets, while mature males had a generalist diet. A significant overlap between sexes and maturity stage diets was found. Diet compositions allowed us to estimate a standardized trophic level of 3.57 for R. glaucostigma. The diet compositions between sexes and maturity stages suggest that all individuals consume similar prey items and have similar trophic roles in the benthic community of the southeastern region of the Gulf of California, where $R$. glaucostigma should be considered a secondary consumer.
\end{abstract}

Key words: guitarfish diet, feeding strategy, trophic level, diet overlap, feeding habitat.

RESUMEN. Para caracterizar los hábitos alimentarios de Rhinobatos glaucostigma (guitarra punteada), se muestrearon los contenidos estomacales de 176 individuos. Los especímenes fueron capturados con redes agalleras por la pesca artesanal que opera frente a Nayarit, México, en la región sureste del golfo de California, durante los periodos de enero a agosto de 2008 y de enero a mayo de 2009 . Para analizar las diferencias de dieta entre sexos y estadios de madurez, se utilizaron las medidas relativas de cuantificación de dieta y métodos no paramétricos multivariados. Las relaciones tróficas y la estrategia de alimentación fueron determinadas con el índice de amplitud de nicho de Levin, el método gráfico de Costello modificado por Amundsen y el índice de traslapo de dietas de Pianka. La dieta global estuvo dominada por crustáceos, principalmente por decápodos, braquiuros y cumáceos. Las dietas fueron similares entre sexos y estadios de madurez, excepto entre hembras y machos maduros. Las hembras maduras y los individuos inmaduros de ambos sexos presentaron una dieta especialista, mientras que los machos maduros tuvieron una dieta generalista. Se encontró un traslapo significativo entre las dietas de ambos sexos y los estadios de madurez. La composición específica de la dieta permitió estimar un nivel trófico estándar de 3.57 para $R$. glaucostigma. La composición de la dieta entre sexos y estadios de madurez sugiere que todos los individuos consumen presas similares y tienen un papel trófico similar en la comunidad bentónica de la región sureste del golfo de California, en donde R. glaucostigma debe ser considerada como un consumidor secundario.

Palabras clave: dieta de pez guitarra, estrategia alimentaria, nivel trófico, traslapo de dietas, habitat de alimentación.

\section{INTRODUCTION}

At the most basic level, the ecological role of a species is defined by its position in the food web. Batoids occupy lower trophic levels $(<4)$ and are considered secondary consumers when compared with most of the large shark species. Still, most of the standardized trophic levels of several batoid species have yet to be estimated (Heithaus et al. 2010). It is predicted that batoids play a critical role in the dynamics of marine ecosystems as predator species at intermediate levels (Ritchie and Johnson 2009), where they are a significant link in food webs in the demersal marine communities (Belleggia

\section{INTRODUCCIÓN}

En el nivel más básico, el papel ecológico de una especie se define por su posición en la red trófica. Los batoideos, con un nivel trófico bajo $(<4)$, están considerados como consumidores secundarios cuando son comparados con la mayoría de las especies de tiburones. Sin embargo, todavía se desconoce el nivel trófico estándar de muchos de ellos (Heithaus et al. 2010). Se predice que los batoideos tienen un papel crítico en la dinámica de los ecosistemas marinos como especies depredadoras a niveles intermedios (Ritchie y Johnson 2009), donde son una liga importante en las redes tróficas de las 
et al. 2008) and an important component of the community structure (Braccini and Perez 2005, Bizzarro et al. 2007, Heithaus et al. 2008). Therefore, quantitative studies of their diet and trophic ecology may contribute towards a better understanding of their ecological role in marine ecosystems, and may facilitate the development of ecosystem-based management approaches (Heithaus et al. 2008, Espinoza et al. 2013).

Guitarfishes (Rhinobatidae) inhabit a variety of habitats such as muddy and sandy bottoms, sea-grass beds, and nearby reefs; in all habitats they feed on bottom species (Barbini et al. 2011, Blanco-Parra et al. 2012). The guitarfish diet is dominated by small crustaceans, fishes being a complementary component (Talent 1982, White et al. 2004, Bizzarro 2005, Downton-Hoffman 2007, Navia et al. 2007, Valadez-González 2007, Payán et al. 2011). However, changes in the diet composition of several ray species have been described to be influenced by sex or maturity stage, as well as spatial and temporal effects (Ellis et al. 1996, Bethea et al. 2004, Bizzarro 2005, Braccini and Perez 2005, Magraña and Gilberto 2007, Robinson et al. 2007, Belleggia et al. 2008, Navia et al. 2011).

The speckled guitarfish, Rhinobatos glaucostigma, is a poorly known fish distributed in the eastern central Pacific Ocean, from the Gulf of California to Ecuador. It is a shallow-water, soft-bottom benthic species showing low mobility (McEachran and Notabartolo-Di-Sciara 1995). Like other species of the genus Rhinobatos, it is an important part of the incidental catch in several fisheries worldwide (Payán et al. 2011). In Mexico, it is caught in artisanal gillnet fisheries off the states of Sonora and Sinaloa (Márquez-Farías and Blanco-Parra 2006), and off Nayarit and Jalisco (GodínezDomínguez et al. 2000). It is also an important component of the incidental catch of the shrimp trawl fishery in the Gulf of California (López-Martínez et al. 2010) and the central Mexican Pacific (Navarro-González et al. 2012). Rhinobatos glaucostigma is part of the ray group catch landed at artisanal camps in Nayarit that showed a yearly average production of $126 \mathrm{t}$ between 2007 and 2011. Locally, after drying, the speckled guitarfish is used in craftwork or traditional medicine (K de la Rosa pers. obs.).

Few studies have focused on the diet of R. glaucostigma across the continental shelf off the central Mexican Pacific. Changes in diet composition associated with seasonality and size of the individuals have been described for the coasts of Colima and Jalisco (Valadez-González 2000, 2007; ValadezGonzález et al. 2006). These studies describe the diet of several species of batoids, including $R$. glaucostigma, noting that stomatopods and decapods are the most important components of the stomach contents. Navarro-González et al. (2012) described the diet of $R$. glaucostigma, among other five batoid species, caught off Sinaloa and Nayarit. They found that crustaceans and mollusks were the most important food components; however, because of the low sample size ( $n=24$ stomach contents) they could not study changes in diet composition associated with sex or other factors. comunidades demersales marinas (Belleggia et al. 2008) y un componente importante de la estructura de la comunidad (Braccini y Perez 2005, Bizzarro et al. 2007, Heithaus et al. 2008). Por lo tanto, los estudios cuantitativos de su dieta y su ecología trófica contribuyen al mejor entendimiento de su papel ecológico y podrían facilitar el desarrollo de medidas de manejo basadas en ecosistemas (Heithaus et al. 2008, Espinoza et al. 2013).

Los peces guitarra (Rhinobatidae) ocupan una variedad de hábitats, como los fondos lodosos y arenosos, bancos de macroalgas y arrecifes cercanos. En todos estos hábitats se alimentan de especies bénticas (Barbini et al. 2011, BlancoParra et al. 2012). Su dieta está dominada por pequeños crustáceos, y los peces son un componente complementario (Talent 1982, White et al. 2004, Bizzarro 2005, DowntonHoffman 2007, Navia et al. 2007, Valadez-González 2007, Payán et al. 2011). Sin embargo, para varias especies, se han descrito cambios en la composición de dieta según el sexo o estado de desarrollo, así como los efectos espaciales o estacionales (Ellis et al. 1996, Bethea et al. 2004, Bizzarro 2005, Braccini y Perez 2005, Magraña y Gilberto 2007, Robinson et al. 2007, Belleggia et al. 2008, Navia et al. 2011).

La guitarra punteada, Rhinobatos glaucostigma, es una raya cuya biología es poco conocida, y se distribuye en el océano Pacífico oriental, desde el golfo de California hasta Ecuador. Es una especie bentónica que habita aguas someras con fondos blandos y muestra poca actividad (McEachran y Notabartolo-Di-Sciara 1995). Así como otras especies del género Rhinobatos, la guitarra punteada forma parte de la captura incidental de muchas pesquerías en el mundo (Payán et al. 2011). En México, es capturada por la pesquería artesanal con redes agalleras en Sonora y Sinaloa (MárquezFarías y Blanco-Parra 2006), así como en Nayarit y Jalisco (Godínez-Domínguez et al. 2000). También forma parte importante de la captura incidental en la pesca del camarón con redes de arrastre del golfo de California (López-Martínez et al. 2010) y el Pacífico central mexicano (NavarroGonzález et al. 2012). Rhinobatos glaucostigma forma parte del grupo de captura denominado rayas que se desembarca en los campos artesanales de Nayarit, con un promedio de captura anual de $126 \mathrm{t}$ de 2007 a 2011. Localmente, esta especie es secada y utilizada como artesanía o en la medicina tradicional (K de la Rosa obs. per.).

Hay pocos estudios sobre la dieta de R. glaucostigma que habita la plataforma continental del Pacífico central mexicano. Para la costa de Colima y Jalisco, se han descrito los cambios en la composición de la dieta de la guitarra punteada conforme a la estacionalidad y el tamaño (Valadez-González 2000, 2007, Valadez-González et al. 2006). En estos estudios se describe la dieta de varias especies de batoideos, incluyendo a $R$. glaucostigma, y se señala que los estomatópodos y los decápodos fueron los componentes más importantes dentro de los contenidos estomacales. Navarro-González et al. (2012) describieron la dieta de R. glaucostigma, junto con otras cinco especies de batoideos, capturada frente a 
To understand the role of $R$. glaucostigma in the benthic community of the region, the objectives of this study were: (1) describe and characterize the diet composition in the southeastern portion of the Gulf of California; (2) assess changes in diet composition in relation to sex or maturity stage, and diet overlap; (3) determine the feeding strategy; and (4) estimate the standard trophic level of this species.

\section{MATERIALS AND METHODS}

\section{Sampling}

Stomachs were collected on a weekly basis from $R$. glaucostigma landed by the artisanal gillnet fishery at the Santa Cruz de Miramar fishing camp, located in Matachén Bay, Nayarit, from January to August 2008 and January to May 2009. Fishing operations were carried out off Nayarit, in the southeastern region of the Gulf of California (fig. 1).

For each individual, the total length (TL, cm) and sex were recorded. The stomachs were removed, bagged, and kept on ice at the sampling site and frozen at the laboratory until their analysis. Females and males were classified into mature and immature categories based on macroscopical observations of their reproductive organs. Maturity of males was determined by the calcification stage of claspers (Clark and von Schmidt 1965, Carrier et al. 2004). For females, the external characteristics of ovaries, and the presence of oocytes and embryos in the uterus was used (Márquez-Farías 2007).

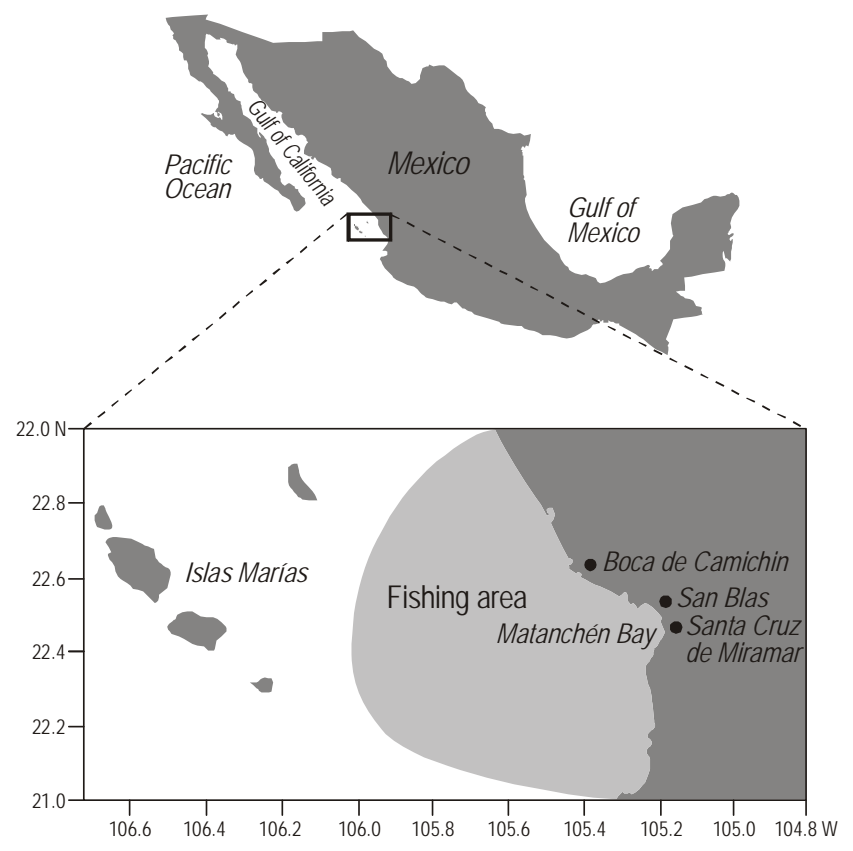

Figure 1. Study area off the coast of Nayarit, Mexico. The shaded area indicates the fishing area.

Figura 1. Área de estudio frente a la costa de Nayarit, México. El área sombreada indica el área de pesca.
Sinaloa y Nayarit. Ellos encontraron que los crustáceos y moluscos fueron los componentes de alimento más importantes; sin embargo, debido al pequeño tamaño de muestra ( $n=24$ contenidos estomacales), ellos no pudieron analizar los cambios en la composición de la dieta con respecto al sexo u otro factor.

Para conocer el papel de R. glaucostigma en la comunidad béntica de la región, los objetivos de este estudio fueron (1) describir y caracterizar la composición de la dieta en la porción sureste del golfo de California; (2) evaluar los cambios en la composición de la dieta conforme al sexo o a los estadios de madurez, y los traslapes entre dietas; (3) determinar la estrategia de alimentación; y (4) estimar el nivel estándar trófico de esta especie.

\section{MATERIALES Y MÉTODOS}

\section{Muestreo}

Se recolectaron semanalmente los estómagos de $R$. glaucostigma desembarcada por la pesquería artesanal con redes agalleras en el campo pesquero Santa Cruz de Miramar, localizado en la bahía de Matanchén, Nayarit, de enero a agosto de 2008 y de enero a mayo de 2009. Las operaciones pesqueras fueron realizadas frente a Nayarit, en la porción sureste del golfo de California (fig. 1).

Para cada individuo, se registró la longitud total (LT, cm) y el sexo. Los estómagos fueron eviscerados, puestos en una bolsa plástica y mantenidos en hielo durante el trabajo de campo, y en el laboratorio fueron congelados hasta su posterior análisis. Las hembras y los machos fueron clasificados en las categorías de inmaduros o maduros con base en las observaciones macroscópicas de sus órganos de reproducción. La madurez de los machos fue determinada conforme al grado de calcificación de su gonopterígio o clasper (Clark y von Schmidt 1965, Carrier et al. 2004). Para las hembras, las características externas de los ovarios y la presencia de ovocitos y embriones en los úteros fueron utilizadas (MárquezFarías 2007).

\section{Análisis de las dietas y evaluación cuantitativa}

Los estómagos fueron descongelados, el contenido estomacal fue removido y las presas fueron separadas y contadas. Cuando fue necesario, los contenidos estomacales fueron lavados con agua utilizando tamices de 1 y $0.45 \mathrm{~mm}$ de tamaño de malla. El peso húmedo de las presas se midió con una balanza analítica $(0.001 \mathrm{~g})$, y las presas se indentificaron al nivel taxonómico más bajo posible (utilizando e.g., Hendrickx 1983, 1999a, 1999b, 1999c, 1999d; Fischer et al. 1995). Después de la identificación taxonómica, las presas fueron separadas en 11 categorías taxonómicas, que en este trabajo se refieren como grupos tróficos según Rogers et al. (2012): anélidos, moluscos, braquiuros, anomuros, decápodos, estomatópodos, cumáceos, ostrácodos, anfípodos, 


\section{Diet analysis and quantitative assessment}

Stomachs were thawed, the contents were removed, and prey items were separated and counted. When necessary, samples were washed with water using 1 - and $0.45-\mathrm{mm}$ sieves. Prey wet mass was weighed on an analytical balance $(0.001 \mathrm{~g})$, and prey were identified to the lowest taxonomic level (using e.g., Hendrickx 1983, 1999a, 1999b, 1999c, 1999d; Fischer et al. 1995). After taxonomic identification, prey were separated into 11 taxonomic categories, referred to here as trophic groups following Rogers et al. (2012): annelids, mollusks, brachyurans, anomurans, decapods, stomatopods, cumaceans, ostracods, amphipods, unidentified crustaceans, and fishes. The number of empty stomachs were recorded and expressed as a percentage of the total number examined for each sex.

Cumulative prey curves were fitted to the number of stomachs sampled to assess if the number of samples analyzed was statistically adequate to describe the diet and to make comparisons between sexes and maturity stages (Ferry and Cailliet 1996, Wetherbee et al. 2012). To eliminate potential biases, the order of the cumulative stomach and prey was randomized 100 times with the EstimatS software (version 8.0, Colwell 2006), following Cortés (1997). To assess sample sufficiency, the mean cumulative ShannonWiener index (with standard deviation) was plotted as a function of sample size.

To estimate the contribution of the prey items to the diet, three relative measures of prey quantity were calculated: percent numerical importance $(\% \mathrm{~N})$, percent frequency of occurrence $(\% \mathrm{FO})$, and percent composition by weight $(\% \mathrm{~W})$, as described by Hyslop (1980) and Cortés (1997). To allow direct comparisons with other studies, the commonly used standardized index of relative importance (\%IRI) (Cortés 1997), which combines the values of the three measures of prey mentioned above, was used. Additionally, for comparing diets between sexes and maturity stages, the geometric index of importance (\%GII) (Assis 1996), which includes \% $\mathrm{N}$ and $\% \mathrm{FO}$, was used. The $\% \mathrm{GII}$ compound index was preferred to the \%IRI because the former is less biased and more precise than the latter (Bizarro et al. 2007), and was thus used for further analysis. For both indices, the standard error was calculated. In order to classify the prey trophic groups, the $\%$ GII values were analyzed following the Assis (1996) approach. Trophic groups with \%GII values $<5 \%$, between $5 \%$ and $20 \%$, and $\geq 20 \%$ were considered occasional or tertiary prey, secondary prey, and preferential or primary prey, respectively.

The program PRIMER v6.1.11 (Clarke and Gorley 2006) was used to test for differences in diet between sexes and maturity stages; a similarity matrix was calculated using the Bray-Curtis similarity coefficient, based on estimated \%GII values. Diet similarity was analyzed by nonmetric multidimensional scaling (NMDS) analysis. NMDS provides a twodimensional graphical representation of guitarfish diets by crustáceos no identificados y peces. El número de estómagos vacíos fue registrado y expresado en porcentaje conforme al número total de estómagos examinados para cada sexo.

Se construyeron curvas acumulativas de presas respecto al número de estómagos analizados para determinar si el tamaño de la muestra era suficiente para describir la dieta y hacer comparaciones entre sexos y estadios de madurez (Ferry y Cailliet 1996, Wetherbee et al. 2012). Para eliminar errores potenciales, se varió el orden acumulativo de entrada de los estómagos y las presas a través de un proceso aleatorio (100 repeticiones) mediante el programa EstimatS (versión 8.0, Colwell 2006), y conforme a Cortés (1997). Para evaluar la suficiencia de muestras, el promedio acumulativo del índice de Shannon-Wiener (con desviación estándar) fue graficado en función del tamaño de muestra.

Para estimar la contribución de cada ítem de la dieta, se calcularon tres medidas relativas de la cantidad de presa: porcentaje numérico de importancia $(\% \mathrm{~N})$; porcentaje de frecuencia de ocurrencia (\%FO); y porcentaje de composición por peso $(\% \mathrm{~W})$, como fueron descritos por Hyslop (1980) y Cortés (1997). Para permitir comparaciones directas con otros estudios, se utilizó el índice estandarizado de importancia relativa (\%IIR) (Cortés 1997), que es comúnmente utilizado y combina los valores de las tres medidas de presas anteriormente mencionadas. Adicionalmente, para comparar las dietas entre sexos y estadios de madurez, se utilizó el índice de importancia geométrico (\%IIG) (Assis 1996), que incluye el $\% \mathrm{~N}$ y $\% \mathrm{FO}$. El uso del índice compuesto \%IIG fue preferido con respecto al \%IIR porque el primero tiene menos error y es más preciso (Bizzarro et al. 2007), y fue utilizado en análisis posteriores. Para ambos índices, se calculó su error estándar. Para clasificar los grupos tróficos, los valores del \%IIG fueron analizados conforme a la aproximación de Assis (1996). Los grupos tróficos con valores del $\%$ IIG $<5 \%$ fueron considerados como presas ocasionales o terciarias; entre $5 \%$ y $20 \%$, como presas secundarias; y $\geq 20 \%$, como presas preferenciales o primarias.

Se utilizó el programa PRIMER v6.1.11 (Clarke y Gorley 2006) para evaluar las diferencias en las dietas entre sexos y estadios de madurez; se construyó una matriz de similitud utilizando el coeficiente de similitud de Bray-Curtis con base en los valores del \%IIG de las presas. La similitud de la dieta fue analizada por medio del análisis de escalamiento multidimensional no paramétrico (NMDS). El NMDS produce una representación gráfica de dos dimensiones de la dieta de las guitarras, uniendo grupos con hábitos alimentarios similares. Posteriormente, se utilizó el análisis de similitud (ANOSIM) para evaluar la hipótesis nula de no diferencias en la composición de dietas entre sexos y estadios de madurez (Platell et al. 1998, Flores-Ortega et al. 2011, Bornatowski et al. 2012). Los valores del estadístico $R$ se utilizaron para describir el grado de similitud (Clarke 1993, Platell et al. 1998, Clarke y Warwick 2001, White et al. 2004); los valores cercanos a 1 indicaron que los dos grupos estaban completamente separados y los valores cercanos a 0 indicaron que no existían diferencias entre los dos grupos. 
clustering groups with similar feeding habits. Afterwards, analyses of similarity (ANOSIM) were used to test the null hypothesis of no difference in the diet composition between sexes and maturity stages (Platell et al. 1998, Flores-Ortega et al. 2011, Bornatowski et al. 2012). The $R$-statistic values were used to describe the extent of similarity (Clarke 1993, Platell et al. 1998, Clarke and Warwick 2001, White et al. 2004), with values near 1 indicating that the two groups are entirely separate and values close to 0 indicating that there are no differences between the two groups.

Diet overlap was calculated using Pianka's index (Winemiller and Pianka 1990, Cortés 1999, Navia et al. 2007) through \%GII values. Overlap is generally considered to be biologically significant when Pianka's index value exceeds 0.60 (Navia et al. 2007). To evaluate the statistical significance of the estimated overlaps, observed overlap values were compared with a distribution of expected values based on simulations of a null model, using the EcoSim v.7.72 program and the algorithm RA3 (Gotelli and Entsminger 2001). Statistical significance estimations followed Bizzarro et al. (2007).

To determine the feeding strategy, the Costello method as modified by Amundsen et al. (1996) for the analysis of stomach content data was used. The analysis is based on a two-dimensional representation of prey-specific abundance and frequency of occurrence (\%FO) of the different prey types in the diet. This method allows prey importance, feeding strategy, and the individual components of the predator niche width to be explored.

Diet breadth was estimated from \%GII values of prey trophic groups, and calculated using Levin's standardized index (Ludwig and Reynolds 1988, Navia et al. 2007). This index ranges from 0 to 1 , with low values indicating diets dominated by few prey (specialist predators), while higher values indicate generalist diets.

The standardized trophic level of R. glaucostigma was calculated using the trophic index proposed by Cortés (1999). Trophic levels of prey categories were taken from the literature (Cortés 1999, Ebert and Bizarro 2007). The \%GII values were used to represent the proportion of each prey taxa in the diet.

\section{RESULTS}

\section{General feeding patterns}

A total of 176 R. glaucostigma stomachs were collected, and $152(86 \%)$ contained prey that could be identified. Of the total examined stomachs, 82 were females $(22.6-87.8 \mathrm{~cm}$ $\mathrm{TL}), 70$ were males (11.8-65.5 cm TL), and 24 were empty (15 females and 9 males). A total of 2645 prey items were identified belonging to 24 taxa grouped into 11 trophic prey groups (table 1). The number of stomachs examined was sufficient to describe the diet of $R$. glaucostigma and examine differences between sexes and maturity stages. The
El traslapo de dietas fue calculado utilizando el índice de Pianka (Winemiller y Pianka 1990, Cortés 1999, Navia et al. 2007) y los valores del \%IIG. Un traslapo mayor que 0.60 conforme al índice de Pianka es generalmente considerado biológicamente significativo (Navia et al. 2007). Para evaluar la significancia estadística de los traslapos estimados, los valores de traslapo observados fueron comparados con una distribución de valores esperados producidos por una simulación de un modelo nulo obtenido mediante el programa EcoSim v7.72 y el algoritmo RA3 (Gotelli y Entsminger 2001). La significancia estadística se estimó conforme a Bizzarro et al. (2007).

Para determinar la estrategia de alimentación, se utilizó el modelo de Costello modificado por Amundsen et al. (1996) para el análisis de contenidos estomacales. Este análisis se basa en la representación en dos dimensiones, la abundancia específica para cada presa y la frecuencia de ocurrencia $(\% \mathrm{FO})$ de los diferentes tipos de presas en la dieta. Este método permite explorar la importancia de cada presa, la estrategia de alimentación y los componentes individuales de la amplitud del nicho del depredador.

La amplitud de la dieta fue estimada con base en los valores del \%IIG de los grupos tróficos y utilizando el índice estandarizado de Levin (Ludwig y Reynolds 1988, Navia et al. 2007). Los valores de este índice tienen un intervalo de 0 a 1 , donde los valores bajos indican una dieta dominada por pocas presas (depredador especialista) y los valores altos indican una dieta generalista.

El nivel trófico estandarizado de $R$. glaucostigma fue calculado utilizando el índice trófico propuesto por Cortés (1999). Los niveles tróficos de las categorías de presas fueron obtenidos de la literatura (Cortés 1999, Ebert y Bizarro 2007). Los valores del \%IIG fueron utilizados para representar las proporciones de cada taxón de la presas en la dieta.

\section{REsultados}

\section{Patrones generales de alimentación}

Se recolectaron un total de 176 estómagos de $R$. glaucostigma, de los cuales $152(86 \%)$ contuvieron presas que fueron posibles de identificar. Del total de estómagos analizados, 82 fueron de hembras $(22.6-87.8 \mathrm{~cm} \mathrm{LT}), 70$ de machos (11.8-65.5 cm LT) y 24 estaban vacíos (15 de hembras y 9 de machos). Se identificaron 2,645 ítems que pertenecieron a 24 taxones que se agruparon en 11 grupos tróficos (tabla 1). El número de estómagos examinados fue suficiente para describir la dieta de R. glaucostigma y para examinar las diferencias en la dieta entre sexos y estadios de madurez. Las curvas de diversidad acumulativa alcanzaron una asíntota con 75 estómagos para el caso de las hembras, 70 para los machos (fig. 2a), 42 para los individuos maduros y 100 para los individuos inmaduros (fig. 2b).

La dieta de R. glaucostigma estuvo conformada por cuatro grandes grupos de presa: anélidos, moluscos, crustáceos y 
Ciencias Marinas, Vol. 39, No. 3, 2013

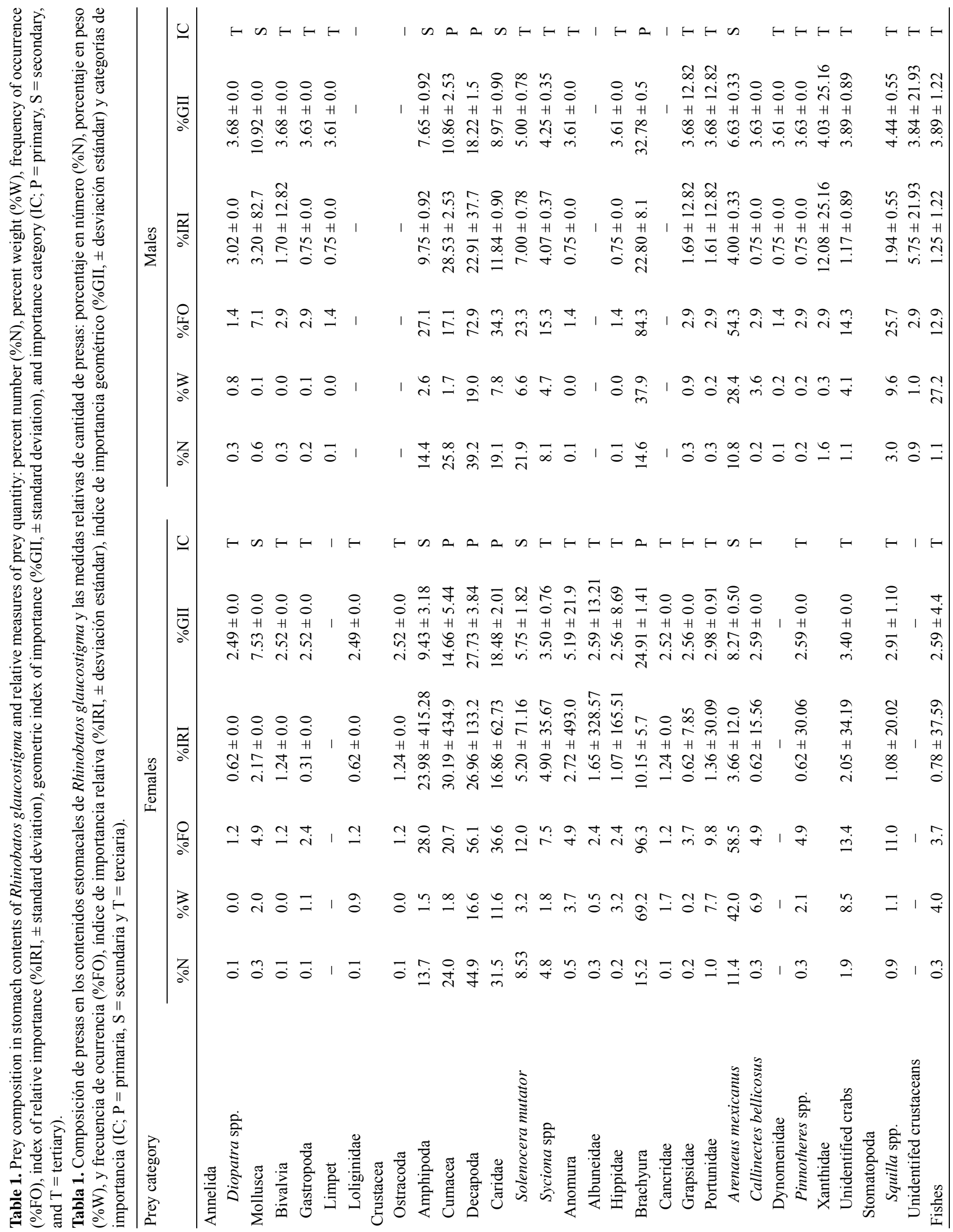



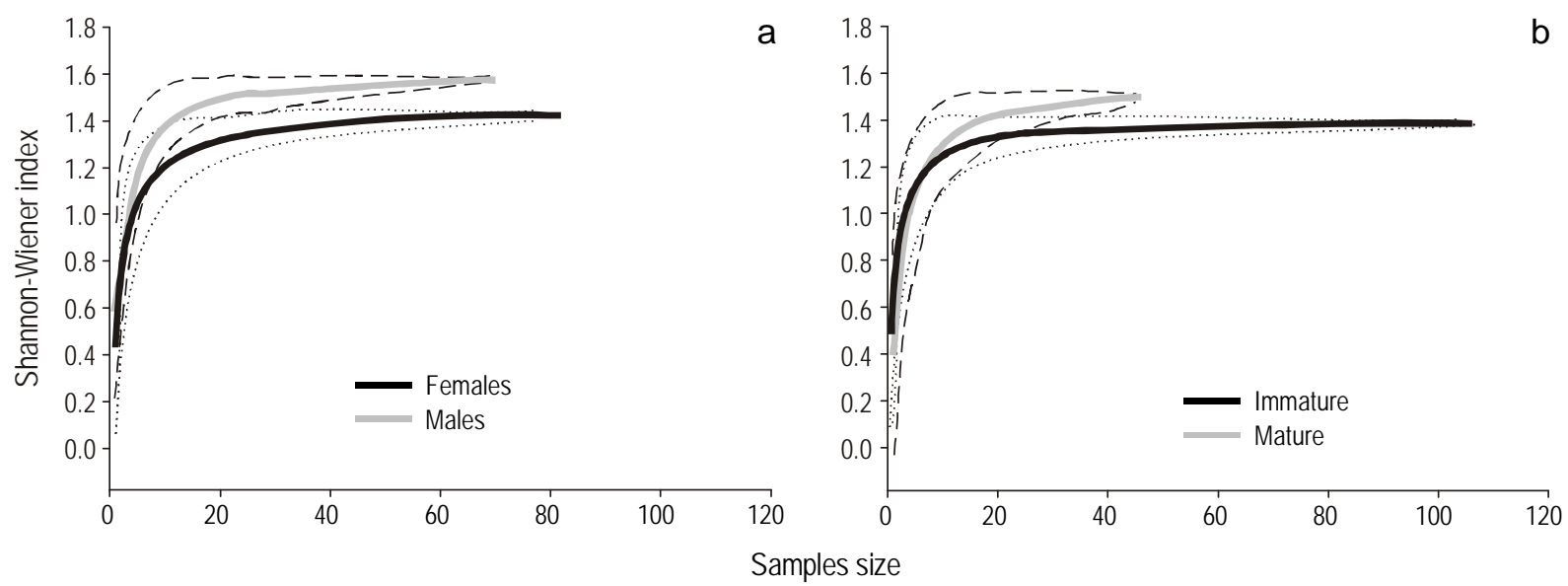

Figure 2. Cumulative prey curves, based on the Shannon-Wiener index, per stomach by (a) sex and (b) maturity stage. Dotted lines represent the standard deviation values.

Figura 2. Curvas acumulativas del índice de Shannon-Wiener por estómago por (a) sexo y (b) estadio de madurez. Las líneas en puntos representan los valores de la desviación estándar.

cumulative diversity curves reached an asymptote at 75 stomachs for females, 70 for males (fig. 2a), 42 for mature individuals, and 100 for immature individuals (fig. 2b).

The diet of R. glaucostigma was composed of four main groups of prey: annelids, mollusks, crustaceans, and fishes. The values of the three relative measures of prey quantity and the compound measures showed that the speckled guitarfish diet was dominated by crustaceans, primarily decapods (predominantly from the infraorder Caridea), brachyurans, and cumaceans. These prey categories were categorized as preferential or primary prey (table 1).

\section{Feeding variability and diet overlap}

The \%GII revealed diet differences between sexes (table 1). The female diet showed a large contribution from decapods $(27.7 \pm 3.8 \% \mathrm{GII})$, brachyurans $(24.9 \pm 1.4 \% \mathrm{GII})$, carideans $(18.5 \pm 2.0 \% \mathrm{GII})$, cumaceans $(14.7 \pm 5.4 \% \mathrm{GII})$, and amphipods $(9.4 \pm 3.2 \% \mathrm{GII})$. In male stomach contents, brachyurans $(32.8 \pm 0.5 \% \mathrm{GII})$, decapods $(18.2 \pm 1.5 \% \mathrm{GII})$, mollusks $(10.9 \pm 0.0 \% \mathrm{GII})$, cumaceans $(10.9 \pm 2.5 \% \mathrm{GII})$, and carideans $(9.0 \pm 0.9 \% \mathrm{GII})$ were the most important prey groups (table 1).

When trophic groups were considered, changes in the diet according to the maturity stage by sex were found (fig. 3). The $\%$ GII values showed that immature females fed more on cumaceans and decapods, when compared with mature females, whereas mature females fed more on brachyurans and anomurans. Stomatopods, ostracods, and annelids were present in high proportions in immature females, while fishes had the largest proportions among the stomach contents of mature females. Also, we found differences in \%GII values of the trophic groups among the male maturity stages; mature males consumed more stomatopods, amphipods, fishes, peces. Los valores de las tres medidas relativas de la cantidad de presa y las medidas compuestas mostraron que la dieta de la guitarra punteada estuvo dominada por los crustáceos, principalmente los decápodos (predominantemente los del infraorden Caridea), los braquiuros y los cumáceos. Estas categorías de presas fueron categorizadas como presas preferenciales o primarias (tabla 1).

\section{Variabilidad de la alimentación y traslapo de dietas}

El \%IIG reveló diferencias en las dietas entre sexos (tabla 1). La dieta de las hembras presentó una gran contribución de los decápodos $(27.7 \pm 3.8 \% \mathrm{IIG})$, braquiuros $(24.9 \pm$ $1.4 \% \mathrm{IIG})$, carídeos $(18.5 \pm 2.0 \% \mathrm{IIG})$, cumáceos $(14.7 \pm$ $5.4 \% \mathrm{IIG})$ y anfípodos $(9.4 \pm 3.2 \% \mathrm{IIG})$. En los contenidos estomacales de los machos, los braquiuros ( $32.8 \pm 0.5 \% \mathrm{IIG})$, decápodos $(18.2 \pm 1.5 \% \mathrm{IIG})$, moluscos $(10.9 \pm 0.0 \% \mathrm{IIG})$, cumáceos $(10.9 \pm 2.5 \% \mathrm{IIG})$ y carídeos $(9.0 \pm 0.9 \% \mathrm{IIG})$ fueron los grupos de presas más importantes (tabla 1).

Cuando se consideraron los grupos tróficos, se encontraron cambios en la dieta según los estadios de madurez por sexo (fig. 3). Los valores del \%IIG mostraron que las hembras inmaduras se alimentaron más de cumáceos y decápodos, en comparación con las hembras maduras, mientras que estas últimas se alimentaron más de braquiuros y anomuros. Los estomatópodos, ostrácodos y anélidos se encontraron presentes en altas proporciones sólo en las dietas de hembras inmaduras, mientras que los peces se encontraron sólo en los contenidos estomacales de las hembras maduras. También se encontraron diferencias entre los valores del \%IIG de grupos tróficos entre los estadios de madurez de los machos; los machos maduros consumieron más estomatópodos, anfípodos, peces y anélidos que los machos inmaduros (fig. 3). Sin embargo, estas diferencias no fueron lo suficientemente grandes, ya que el gráfico de ordenación 


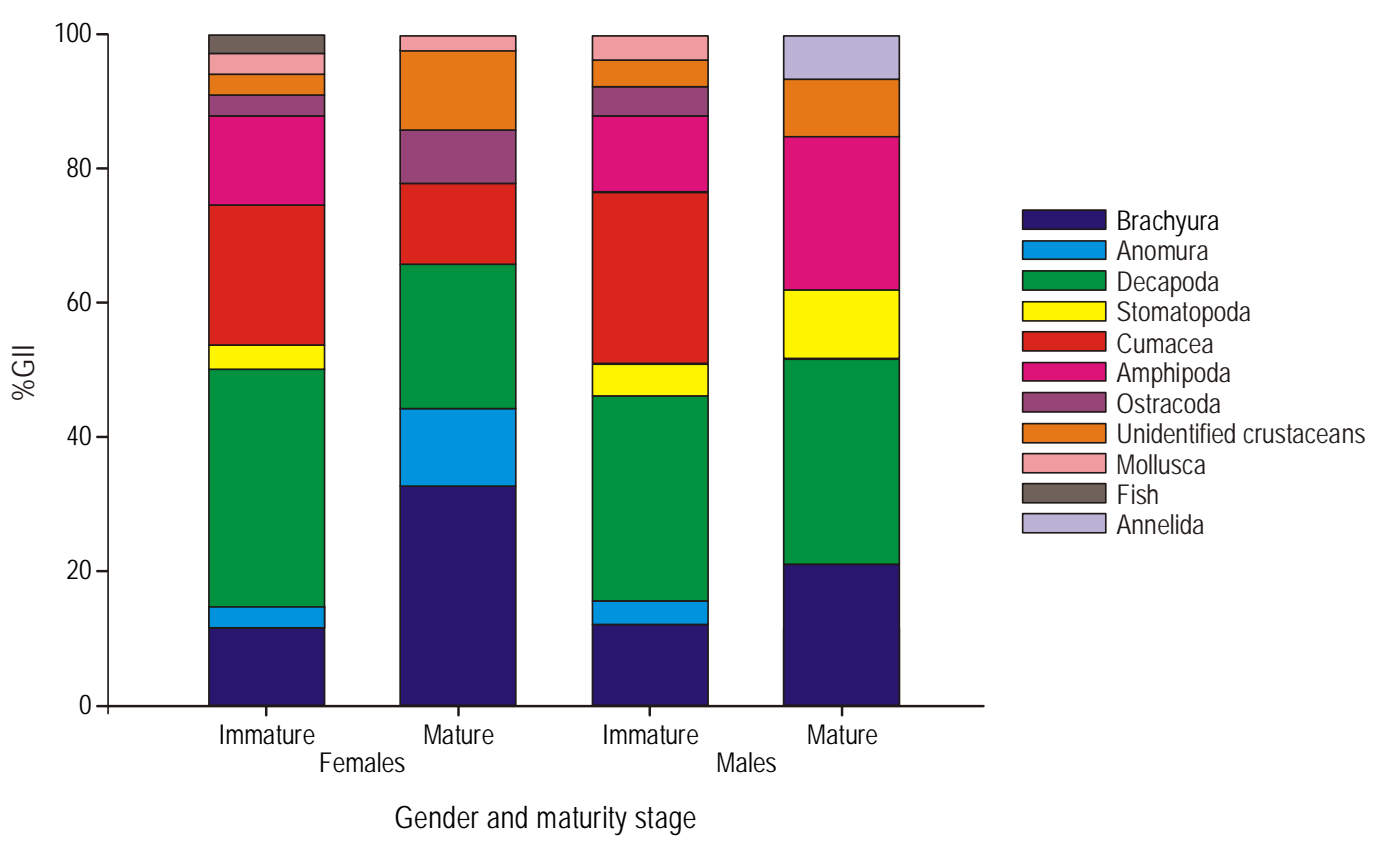

Figure 3. Major prey categories in stomach contents of Rhinobatos glaucostigma by sex and maturity stage, based on the geometric index of importance $(\% \mathrm{GII})$.

Figura 3. Principales categorías de presas en los contenidos estomacales de Rhinobatos glaucostigma por sexo y estadio de madurez, con base en el índice geométrico de importancia (\%GII).

and annelids than immature males (fig. 3). However, these differences were not large enough, and the NMDS ordination plot did not reveal the formation of groups (Stress $=0.13$; fig. 4) and ANOSIM found no significant differences between female and male diets $(R=0.042, P<0.05)$. The $\mathrm{R}$ value suggested no differences between the diets of the immature guitarfish of both sexes $(R=0.003, P<0.10)$. On the other hand, differences between mature female and mature male diets were found $(R=0.327, P<0.01)$.

Pairwise comparisons of Pianka's indexes among sexes and maturity stages showed significant observed overlap values $(>0.69)$. This was ratified by the significant $P$ values after comparing to the null model results (table 2).
NMDS no reveló la formación de ningún grupo (Stress = 0.13 ; fig. 4) y el ANOSIM no mostró diferencias significativas entre las dietas de hembras y machos $(R=0.042, P<$ $0.05)$. El valor de $\mathrm{R}$ sugirió la ausencia de diferencias significativas entre los organismos inmaduros de ambos sexos $(R=$ $0.003, P<0.10)$. Por otro lado, se encontraron diferencias entre las dietas de las hembras maduras y los machos madu$\operatorname{ros}(R=0.327, P<0.01)$.

Las comparaciones pareadas de los índices de Pianka entre los sexos y los estadios de madurez mostraron un traslapo observado significativo $(>0.69)$. Esta tendencia fue comprobada con los valores significativos de $P$ al comparar los resultados del modelo nulo (tabla 2).

Table 2. Dietary overlap by sex and maturity stage of Rhinobatos glaucostigma, and significant values of the null model for each evaluated overlap $(P)$. Overlap index = Pianka's index; modeled overlap = simulated Pianka's index values with the null model.

Tabla 2. Traslapo de dietas entre sexos y estadios de madures de Rhinobatos glaucostigma, y los valores de significancia del modelo nulo con respecto a cada traslapo evaluado $(P)$. Índice de traslape $=$ índice de Pianka; traslape modelado $=$ valores simulados a partir del índice de Pianka usando el modelo nulo.

\begin{tabular}{lccc}
\hline Evaluated overlap & Overlap index & Modeled overlap & $P$ \\
\hline Females vs males & 0.98 & 0.50 & $<0.001$ \\
Immature females vs mature females & 0.73 & 0.45 & $<.01$ \\
Immature males vs mature males & 0.75 & 0.46 & $<0.05$ \\
Immature females vs immature males & 0.98 & 0.45 & $<.001$ \\
Mature females vs mature males & 0.69 & 0.43 & $<0.01$ \\
Immature females vs mature males & 0.81 & 0.45 & $<0.01$ \\
Mature females vs immature males & 0.74 & $<$ \\
\hline
\end{tabular}




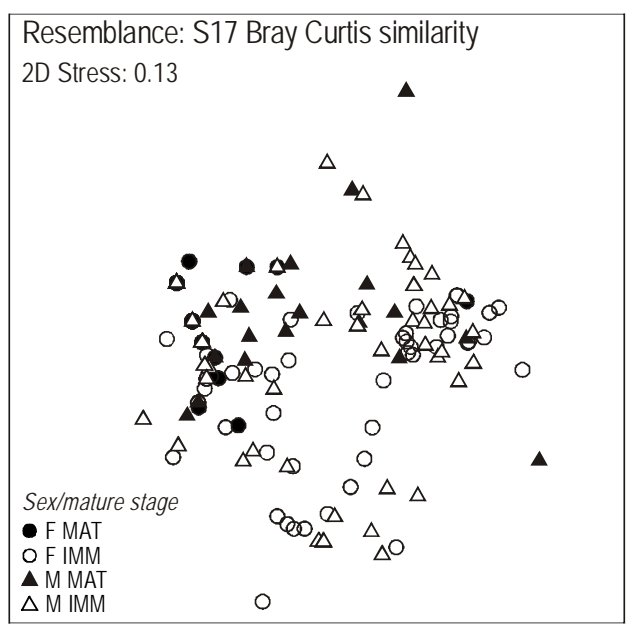

Figure 4. Ordinations from nonmetric multidimensional scaling analysis among sexes and maturity stages of Rhinobatos glaucostigma $(\mathrm{F}$ MAT $=$ mature female, $\mathrm{F}$ IMM $=$ immature female, $\mathrm{M}$ MAT = mature male, and M IMM = immature male).

Figura 4. Ordenación conforme al análisis de escalamiento multidimensional no métrico entre sexos y estadios de madurez de Rhinobatos glaucostigma. (F MAT $=$ hembras maduras, $\mathrm{F}$ IMM $=$ hembras inmaduras, $\mathrm{M}$ MAT $=$ machos maduros, $\mathrm{y}$ $\mathrm{M} \mathrm{IMM}=$ machos inmaduros).

\section{Feeding strategy and diet breadth by sex and maturity stage}

The graphical analysis of feeding strategies showed that females (fig. 5a) and males (fig. 5b) tend to specialize in the feeding of decapods and cumaceans. The points located in the lower left corner of figure $5(\mathrm{a}, \mathrm{b})$ represent rare and less important prey such as fishes, mollusks, stomatopods, and annelids. Levin's standardized index indicated that females and males are specialists with a diet breadth of $B_{i}=0.26$ and $B_{i}=0.31$, respectively. When maturity stage was considered, immature females $\left(B_{i}=0.24\right)$, mature females $\left(B_{i}=0.25\right)$, and immature males $\left(B_{i}=0.30\right)$ showed a specialized diet, while mature males presented a value of a more generalist diet $\left(B_{i}=0.53\right)$.

\section{Standardized trophic level}

Mean trophic level for $R$. glaucostigma was estimated at 3.57 , with preferential feeding on invertebrates. Trophic levels for female and males were very similar (3.562 and 3.566 , respectively).

\section{DISCUSSION}

The results of this study show that the main prey in the diet composition of $R$. glaucostigma were crustaceans, primarily decapods, brachyurans, and cumaceans, indicating

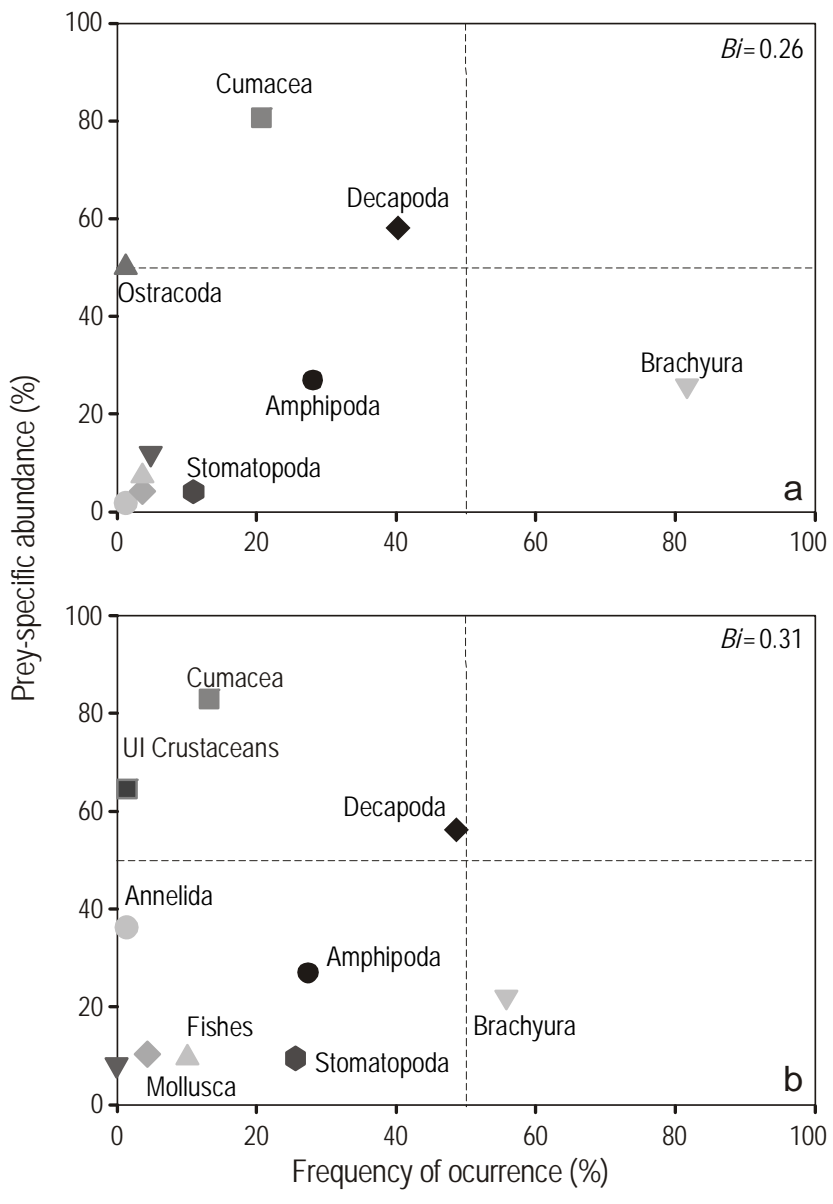

Figure 5. Feeding strategy diagram for (a) female and (b) male individuals of Rhinobatos glaucostigma, based on Amundsen et al. (1996). Each point represents each prey trophic group. Diet breadth index $(\mathrm{Bi})$ values are also included. UI = unidentified.

Figura 5. Diagrama de la estrategia de alimentación para (a) hembras y (b) machos de Rhinobatos glaucostigma, con base en Amundsen et al. (1996). Cada punto representa un grupo trófico presa. También se incluye el valor del índice de amplitud de dieta (Bi). UI = no identificado.

\section{Estrategia de alimentación y amplitud de la dieta por sexo y estadio de madurez}

El análisis gráfico de estrategias de alimentación mostró que las hembras (fig. 5a) y los machos (fig. 5b) tienden a especializarse en la alimentación basada en decápodos y cumáceos. Los puntos localizados en la esquina inferior de las figuras $5(\mathrm{a}, \mathrm{b})$ representan las presas raras y menos importantes, como fueron los peces, moluscos, estomatópodos y anélidos. El índice estandarizado de Levin indicó que las hembras y los machos son especialistas en su amplitud de dieta, con valores de $B_{i}=0.26$ y $B_{i}=0.31$, respetivamente. Cuando los estadios de madurez fueron considerados, las hembras inmaduras $\left(B_{i}=0.24\right)$, las hembras maduras $\left(B_{i}=0.25\right)$ y los machos inmaduros $\left(B_{i}=0.30\right)$ mostraron 
benthic feeding habits, as is common among guitarfishes (Navia et al. 2007, Barbini et al. 2011, Payán et al. 2011, Blanco-Parra at al. 2012, Navarro-González et al. 2012, Espinoza et al. 2013). However, these results contrast with those of other feeding studies for the same species in the region. Off the central Mexican Pacific the main prey of $R$. glaucostigma were stomatopods and decapods (ValadezGonzález et al. 2006), while off Nayarit and Sinaloa they were decapods and mollusks (Navarro-González et al. 2012). Valadez-González et al. (2006) found significant differences between seasons in the diet of $R$. glaucostigma, where stomatopods were more important during the autumn, while decapods were more important during the summer. Similar to our results for the immature specimens, they also found that stomatopods were more important in the smaller-sized guitarfish diets $(<70 \mathrm{~cm} \mathrm{TL})$. Even though the sample size of Navarro-González et al. (2012) was small $(n=24)$, their results show a diet composed $\sim 99 \%$ by decapods, primarily by penaeid shrimp. In our study other decapods like brachyurans and carideans were the most important food item. The differences in the results of these three studies could be related to either differences in geographical origin of the samples, in fishing gear used for sampling, in sampled habitats, or in sampling period, or a combination of them. Our samples came from the artisanal gillnet fishery operating on the continental shelf off Nayarit (fig. 1) from late winter to summer, when $R$. glaucostigma are landed. ValadezGonzález et al. (2006) obtained samples monthly onboard research vessels operating a bottom trawl net on the continental shelf off Colima and Jalisco from September 1997 to August 1998. Navarro-González et al. (2012) obtained samples onboard commercial shrimp trawlers operating on the continental shelf off Nayarit and Sinaloa from September 2006 to March 2007. Future research to understand the feeding behavior of R. glaucostigma should take into consideration these factors while designing the study, to assure comparisons between different studies. Special care has to be taken to ensure a complete annual cycle, in order to guarantee that oceanographic yearly variance is represented in the sample. Rinewalt et al. (2007), found significant differences in the diet by sex, maturity stage, and oceanographic season for the sandpaper skate, Bathyraja kincaidii, off central California after analyzing samples representing a one-year cycle (June 2006 to July 2007).

The diet composition of several skate species have shown both generalist and specialist feeding strategies (Magraña and Gilberto 2007, Rinewalt et al. 2007, Treolar et al. 2007, Payán et al. 2011, Espinoza et al. 2013). Furthermore, ontogenetic changes in feeding strategy have also been reported, where organisms behave as generalists when young and become specialists as adults (Belleggia et al. 2008). In this study, Levin's standardized index and the modified Costello graphic method showed that both females and males are specialists. The graphic method used considers a predator as una dieta especializada, mientras que los machos maduros presentaron un valor de una dieta más generalista $\left(B_{i}=0.53\right)$.

\section{Nivel trófico estandarizado}

El nivel trófico estandarizado para $R$. glaucostigma fue estimado en 3.57, con una alimentación basada en invertebrados. El nivel trófico de hembras y machos fue muy similar (3.562 y 3.566 , respectivamente).

\section{Discusión}

Los resultados de este estudio muestran que la presas principales en la composición de la dieta de R. glaucostigma fueron los crustáceos, principalmente decápodos, braquiuros y cumáceos, indicando hábitos alimentarios bentónicos, que es lo común en peces guitarra (Navia et al. 2007, Barbini et al. 2011, Payán et al. 2011, Blanco-Parra et al. 2012, Navarro-González et al. 2012, Espinoza et al. 2013). Estos resultados contrastan con aquellos obtenidos en otros estudios alimentarios para la especie en la región. Frente al Pacífico central mexicano, las presas principales de $R$. glaucostigma fueron los estomatópodos y los decápodos (Valadez-González et al. 2006), mientras que frente a Nayarit y Sinaloa fueron los decápodos y los moluscos (NavarroGonzález et al. 2012). Valadez-González et al. (2006) encontraron diferencias significativas en las dietas de $R$. glaucostigma entre las estaciones del año; los estomatópodos fueron más importantes durante el otoño, mientras que los decápodos lo fueron durante el verano. De una manera similar a nuestros resultados de los organismos inmaduros, estos autores encontraron que los estomatópodos fueron más importantes dentro de las dietas de guitarras pintas de tallas menores $(<70 \mathrm{~cm} \mathrm{LT})$. Por otro lado, a pesar de que el tamaño de muestra de Navarro-González et al. (2012) fue pequeño $(n=24)$, sus resultados mostraron que la dieta estaba compuesta en un $\sim 99 \%$ por decápodos, principalmente por camarones de la familia Penaeidae. En nuestro estudio, otros decápodos fueron los ítems de alimento más importantes, como los braquiuros y carídeos. Las diferencias de los resultados entre estos tres estudios podrían deberse a las diferencias en el origen geográfico de las muestras, en las artes de pesca usadas durante los muestreos, en los hábitats muestreados o en el periodo de muestreo, o a una combinación de éstas. Nuestras muestras provienen de la pesquería artesanal con redes agalleras que opera en la plataforma continental frente a Nayarit (fig. 1) durante los meses del invierno tardío al verano, cuando $R$. glaucostigma es capturada. Las muestras de Valadez-González et al. (2006) fueron obtenidas mensualmente a bordo de buques de investigación que operaron una red de arrastre de fondo en la plataforma continental de Colima y Jalisco de septiembre de 1997 a agosto de 1998. Las muestras de Navarro-González et al. (2012) fueron obtenidas a bordo de embarcaciones de pesca comercial de arrastre para camarón que operaron en la plataforma continental 
specialist when few individuals of a population consume prey with high specific abundance and low occurrence in the stomachs (Amundsen et al. 1996). When analyzed by maturity stages, our data indicate that mature and immature females and males showed a clear tendency for specialization, feeding on crustaceans, brachyurans, decapods, and cumaceans. Nevertheless, both sexes in both maturity stages occasionally feed on other trophic groups, which might diminish intraspecific competition.

Our results show a significant similarity among the diets of females, males, and both maturity stages, except for the slight difference between mature females and males $(R=$ 0.32). However, the extent of overlap between diets among sexes and maturity stages was highly significant, indicating a very similar use of food resources. Care has to be taken with this result because the high level of taxonomic grouping of prey categories used for this analysis (e.g., decapods and brachyurans) could have increased the similarity of the diets between sexes and maturity stages (Navia et al. 2011). Nevertheless, grouping prey categories is very common in feeding studies (Wetherbee et al. 2012), and our results should be compared within this context.

Fish morphology plays an important role in determining the type of prey consumed, while morphological variation can lead to changes in foraging ability and subsequently differential exploitation of food resources and trophic level (Karpouzi and Stergiou 2003). The feeding mechanism of guitarfish has been described in detail; prey is captured by suction using the mouth, followed by a bite to finalize prey ingestion (Wilga and Motta 1998). Dental morphology of $R$. glaucostigma shows teeth with rounded cusps with a greater number of tooth rows in the lower jaw, where teeth are longer and deeper, allowing a strong and compressed bite (de la Rosa-Meza 2010). The morphology and feeding ability of R. glaucostigma, and the dominance of epibenthic decapod species in its diet, suggest that most of the feeding activity of this species takes place upon the substratum rather than within it, as has been suggested for other batoids (Barbini et al. 2011, Navia et al. 2011).

Ebert and Bizzarro (2007) estimated the standardized trophic level of 60 skate species and obtained values between 3.48 and 4.22 . In this study we estimated a standardized trophic level of 3.57 for $R$. glaucostigma. This value is highly influenced by the large proportion of invertebrates in the diet (Treolar et al. 2007, Blanco-Parra et al. 2012). The diets of other species of Rhinobatidae are composed mainly of decapod crustaceans, and trophic level values similar to those obtained in this study are expected. However, other batoid species might show different trophic level values, because their diet could also include high proportions of polychaetes, amphipods, mollusks, and lacelets (Ebert and Bizzarro 2007, Navia et al. 2007, Barbini et al. 2011, Navarro-González et al. 2012), and small benthic fishes (Flores-Ortega et al. 2011). de Nayarit y Sinaloa de septiembre de 2006 a marzo de 2007. Para investigaciones futuras del comportamiento alimentario de $R$. glaucostigma, se deberán de tomar en cuenta estos factores durante el diseño de los estudios, para así asegurar las posibles comparaciones entre estudios. Se debe tomar cuidado especial en cubrir un ciclo anual completo durante los muestreos, para poder así garantizar que la variación oceanográfica anual está representada en las muestras. Rinewalt et al. (2007) encontraron diferencias significativas en las dietas por sexo, estadio de madurez y temporada oceanográfica para la raya Bathyraja kincaidii, frente a la parte central de California, después de analizar las muestras de un ciclo anual (de junio de 2006 a julio de 2007).

La composición de la dieta de varias especies de raya ha revelado tanto estrategias de alimentación especialistas como generalistas (Magraña y Gilberto 2007, Rinewalt et al. 2007, Treolar et al. 2007, Payán et al. 2011, Espinoza et al. 2013). También se han documentado cambios ontogenéticos en las estrategias de alimentación, en los que los organismos que se comportan como generalistas cuando juveniles se convierten en especialistas cuando adultos (Belleggia et al. 2008). En el presente estudio, el índice estandarizado de Levin y el método gráfico de Costello modificado mostraron que tanto las hembras como los machos son principalmente especialistas. El método gráfico utilizado considera a un depredador como especialista cuando pocos individuos de la población consumen presas con una abundancia específica alta pero con una ocurrencia en los estómagos baja (Amundsen et al. 1996). Cuando nuestros resultados fueron analizados por estadios de madurez, indicaron que las hembras y los machos en ambos estadios de madurez (maduro e inmaduro) mostraron una tendencia clara hacia la especialización, alimentándose de crustáceos, braquiuros, decápodos y cumáceos. No obstante, los individuos de ambos sexos y estadios de madurez se alimentaron de otros grupos tróficos ocasionalmente, lo cual posiblemente disminuye la competencia intraespecífica.

Nuestros resultados muestran una similitud significativa entre las dietas de hembras, machos y ambos estadios de madurez, excepto por la pequeña diferencia encontrada entre las hembras y machos maduros $(R=0.32)$. Sin embargo, la extensión del traslapo entre las dietas entre sexos y estadios de madurez fue altamente significativo, indicando un uso similar de los recursos alimentarios. Estos resultados se deben de ver con ciertas reservas, porque el alto nivel de agrupación taxonómica de las categorías de presas utilizado en este estudio (e.g., decápodos y braquiuros) puede incrementar la similitud de las dietas entre el sexo y los estadios de madurez (Navia et al. 2011). No obstante, el agrupar categorías de presas es muy común entre los estudios de alimentación (Wetherbee et al. 2012), y es dentro de este contexto que nuestros resultados deben de ser comparados.

La morfología de los peces tiene un papel importante en la determinación del tipo de presa que consumen. La variación morfológica puede causar cambios en la habilidad de 
Finally, our results show that there is no clear sexual segregation in the diet of $R$. glaucostigma, and the significant overlap in the diet composition among sexes and maturity stages suggest that these groups consume similar prey items and have similar trophic roles in the benthic community of the southeastern region of the Gulf of California (San Martin et al. 2007, Belleggia et al. 2008). Due to its standardized trophic level (3.57), R. glaucostigma should be considered a secondary consumer in food web dynamic analyses of the marine benthic communities of this region.

\section{ACKNOWLEDGMENTS}

The first author thanks the National Council for Science and Technology (CONACYT, Mexico) for financial support through a scholarship during her postgraduate studies. We thank Miguel Regalado de Dios and the artisanal fishermen from the Santa Cruz de Miramar community for all their support during sampling. We also thank Juan Carlos PérezJiménez, Benjamín Barón, and two anonymous reviewers for critical comments on the first drafts of this article in the Spanish version.

\section{REFERENCES}

Amundsen PA, Gabler HM, Staldvik FJ. 1996. A new approach to graphical analysis of feeding strategy from stomach contents data - modification of the Costello (1990) method. J. Fish Biol. 48: $607-614$. http://dx.doi.org/10.1111/j.1095-8649.1996.tb01455.x

Assis C. 1996. A generalized index for stomach contents analysis in fish. Sci. Mar. 60: 385-389.

Barbini SA, Lucifora LO, Hozbor NM. 2011. Feeding habits and habitat selectivity of the shortnose guitarfish, Zapteryx brevirostris (Chondrichthyes, Rhinobatidae), off north Argentina and Uruguay. Mar. Biol. Res. 7: 365-377. http://dx.doi.org/10.1080/17451000.2010.515229

Belleggia M, Mabragaña E, Figueroa DE, Scenna LB, Barbini SA, Díaz de Astarloa J. 2008. Food habits of the broad nose skate, Bathyraja brachyurops (Chondrichthyes, Rajidae), in the southwest Atlantic. Sci. Mar. 72: 701-710. http://dx.doi.org/10.3989/scimar.2008.72n4701

Bethea DM, Buckel JA, Carlson JK. 2004. Foraging ecology of the early life stages of four sympatric shark species. Mar. Ecol. Prog. Ser. 268: 245-264. http://dx.doi.org/10.3354/meps268245

Bizzarro JJ. 2005. Fishery biology and feeding ecology of rays in Bahía Almejas, Mexico. MSc thesis, California State University, San Francisco; Moss Landing Marine Laboratories, 468 pp.

Bizzarro JJ, Robinson HJ, Rinewalt CS, Ebert DA. 2007. Comparative feeding ecology of four sympatric skate species off central California, USA. Environ. Biol. Fish. 80: 197-220. http://dx.doi.org/10.1007/s10641-007-9241-6

Blanco-Parra MP, Galván-Magaña F, Márquez-Farías JF, NiñoTorres CA. 2012. Feeding ecology and trophic level of the banded guitarfish, Zapteryx exasperata, inferred from stable isotopes and stomach contents analysis. Environ. Biol. Fish. 95: 65-77.

http://dx.doi.org/10.1007/s10641-011-9862-7

Bornatowski H, Heithaus MR, Albilhoa V, Corrêa MFM. 2012. Feeding of the Brazilian sharpnose shark Rhizoprionodon forrajeo, causando subsecuentemente una diferencia en el nivel trófico y en el uso de los alimentos (Karpouzi y Stergiou 2003). El mecanismo para la alimentación de los peces guitarra ha sido descrito en detalle; la presa es capturada por succión, seguido por una mordida para finalizar la ingestión de la presa (Wilga y Motta 1998). La morfología dental de $R$. glaucostigma muestra dientes con cúspides redondeadas, con un número mayor de hileras de dientes en la mandíbula inferior, donde los dentarios son largos y profundos, que permiten una mordida fuerte con presión (De la Rosa-Meza 2010). La morfología y la habilidad de alimentación de $R$. glaucostigma, y la dominancia de decápodos epibénticos en su dieta, sugieren que la gran mayoría de las actividades alimentarias de esta especie se llevan acabo sobre el sustrato, en lugar que dentro del sustrato, así como ha sido sugerido para otros batoideos (Barbini et al. 2011, Navia et al. 2011).

Ebert y Bizzarro (2007) estimaron el nivel trófico estándar de 60 especies de rayas y obtuvieron valores de entre 3.48 y 4.22 . En este estudio, nosotros estimamos un nivel trófico estandarizado de 3.57 para $R$. glaucostigma. Este valor está influenciado principalmente por la alta proporción de invertebrados en su dieta (Treolar et al. 2007, Blanco-Parra et al. 2012). Las dietas de otras especies de Rhinobatidae están compuestas principalmente por crustáceos decápodos, por lo que se esperarían niveles tróficos similares al encontrado en este estudio. Sin embargo, es posible que otras especies de batoideos tengan niveles tróficos diferentes, debido a que sus dietas también incluyen altas proporciones de poliquetos, anfípodos, moluscos y lanceletas (Ebert y Bizzarro 2007, Navia et al. 2007, Barbini et al. 2011, Navarro-González et al. 2012), así como peces bentónicos (Flores-Ortega et al. 2011).

Finalmente, nuestros resultados muestran que no hay una segregación clara entre sexos conforme a la dieta de $R$. glaucostigma, y el traslapo significativo en las dietas entre los sexos y estadios de madurez sugieren que estos grupos consumen presas similares y tienen un papel trófico similar en la comunidad bentónica de la región sureste del golfo de California (San Martin et al. 2007, Belleggia et al. 2008). Debido a su nivel trófico estandarizado (3.57), R. glaucostigma se debe considerar como un consumidor secundario cuando se analice la dinámica de la red alimentaria de las comunidad marinas bentónicas de esta región.

\section{Agradecimientos}

La primera autora agradece al Consejo Nacional de Ciencia y Tecnología (CONACYT) su apoyo financiero a través de una beca durante sus estudios de postgrado. Agradecemos a Miguel Regalado de Dios y a los pescadores artesanales de la comunidad de Santa Cruz de Miramar todo su apoyo durante el muestreo. También agradecemos a Juan Carlos Pérez-Jiménez, Benjamín Barón y dos revisores anónimos sus comentarios críticos sobre las primeras versiones de este artículo en español. 
lalandii (Müller and Henle 1839) from southern Brazil. J. Appl. Ichthyol. 28: 623-627. http://dx.doi.org/10.1111/j.1439-0426.2012.01970.x

Braccini JM, Perez JE. 2005. Feeding habits of the sandskate Psammonatis extenta (Garman 1913): Sources of variation in dietary composition. Mar. Freshwat. Res. 56: 395-403. http://dx.doi.org/10.1071/MF04205

Carrier JC, Pratt HL, Castro JL. 2004. Reproductive biology of elasmobranchs. In: Carrier JC, Musick JA, Heithaus MR (eds.), Biology of Sharks and their Relatives. CRC Press, Boca Raton, pp. 269-286.

Clark E, von Schmidt K. 1965. Sharks of the central Gulf of Florida. Bull. Mar. Sci. 15: 13-83.

Clarke KR. 1993. Non-parametric multivariate analysis of change in community structure. Aust. J. Ecol. 18: 117-143. http://dx.doi.org/10.1111/j.1442-9993.1993.tb00438.x

Clarke K, Warwick R. 2001. Change in marine communities: An approach to statistical analysis and interpretation. PRIMER-E, Plymouth, UK, 172 pp.

Clarke K, Gorley R. 2006. PRIMER v6: User manual/tutorial. PRIMER-E, Plymouth, UK, 192 pp.

Colwell RK. 2006. EstimateS: Statistical estimation of species richness and shared species from samples. Version 8. Persistent URL < purl.oclc.org/estimates>.

Cortés E. 1997. A critical review of methods of studying fish feeding based on analysis of stomach content: Application to elasmobranch fishes. Can. J. Fish. Aquat. Sci. 54: 726-738. http://dx.doi.org/10.1139/f96-316.

Cortés E. 1999. Standardized diet compositions and trophic levels of sharks. J. Mar. Sci. 56: 707-717. http://dx.doi.org/10.1006/jmsc.1999.0489

De la Rosa-Meza K. 2010. Ecomorfología mandibular y dieta de batoideos en el Golfo de California. PhD thesis, Centro de Investigación Científica y de Educación de Ensenada, México, $308 \mathrm{pp}$.

Downton-Hoffman C. 2007. Biología del pez guitarra Rhinobatos productus (Ayres 1856), en Baja California Sur, México. PhD thesis, CICIMAR-IPN, La Paz, México, 194 pp.

Ebert DA, Bizzarro JJ. 2007. Standardized diet compositions and trophic levels of skates (Chondrichthyes: Rajiformes: Rajoidei). Environ. Biol. Fish. 80: 221-237. http://dx.doi.org/10.1007/s10641-007-9227-4

Ellis JR, Pawson MG, Shackley SE. 1996. The comparative feeding ecology of six species of shark and four species of ray (Elasmobranchii) in the north-east Atlantic. J. Mar. Biol. Assoc. UK 76: 89-106. http://dx.doi.org/10.1017/S0025315400029039

Espinoza M, Clarke TM, Villalobos-Rojas F, Wehrtmann IS. 2012. Ontogenetic dietary shift and feeding ecology of the rasptail skate Raja velezi and the brown smoothhound shark Mustelus henlei along the Pacific coast of Costa Rica, Central America. J. Fish Biol. 81: 1578-1595. http://dx.doi.org/10.1111/j.1095-8649.2012.03410.x

Espinoza M, Clarke TM, Villalobos-Rojas F, Wehrtmann IS. 2013. Diet composition and diel feeding behavior of the banded guitarfish Zapteryx xyster along the Pacific coast of Costa Rica, Central America. J. Fish Biol. 82: 286-305. http://dx.doi.org/10.1111/j.1095-8649.2012.03488.x

Fischer W, Krupp F, Schneider W, Sommer C, Carpenter K, Niem V. 1995. Guía FAO para la identificación de especies para los fines de la pesca. Pacífico centro-oriental. FAO, Rome. Vol. I, 646 pp.

Ferry L, Cailliet GM. 1996. Sample size and data analysis: Are we characterizing and comparing diet properly? In: MacKinlay D, Shearer K (eds.), Feeding Ecology and Nutrition in Fish: Proceedings of the Symposium of the Feeding Ecology and
Nutrition in Fish. International Congress on the Biology of Fishes. American Fisheries Society, San Francisco, pp. 71-80.

Flores-Ortega JR, Godínez-Domínguez E, González-Sansón G, Rojo-Vázquez JA, Corgos A. Morales-Jáuregui MY. 2011. Feeding habits of three round stingrays (Rajiformes: Urotrygonidae) in the central Mexican Pacific. Cienc. Mar. 37: 279-292.

Godínez-Domínguez E, Rojo-Vázquez J, Galván-Piña V, AguilarPalomino B. 2000. Changes in the structure of a coastal fish assamblage exploited by a small scale gillnet fishery during an El Niño-La Niña event. Estuar. Coast. Shelf Sci. 51: 773-787. http://dx.doi.org/10.1006/ecss.2000.0724

Gotelli N, Entsminger G. 2001. EcoSim: Null models software for ecology. 7.0 ed. Acquired Intelligence Inc. \& Kesey-Bear, VT 05465 .

Heithaus MR, Frid A, Wirsing AJ, Worm, B. 2008. Predicting ecological consequences of marine top predator declines. Trends Ecol. Evol. 23: 202-210.

http://dx.doi.org/10.1016/j.tree.2008.01.003

Heithaus MR, Frid A, Vaudo JJ, Worm B, Wirsing AJ. 2010. Unraveling the ecological importance of elasmobranchs. In: Carrier JC, Musick JA, Heithaus MR (eds.), Sharks and Their Relatives. II. Biodiversity, Adaptive Physiology and Conservation. CRC Press, Boca Raton, pp. 611-637.

Hendrickx M. 1983. Estudio de la fauna marina y costera del sur de Sinaloa, México. III. Clave de identificación de los cangrejos de la familia Portunidae (Crustacea: Decápoda). An. Inst. Cienc. Mar. Limnol. Univ. Nac. Auton. Mex. 11: 49-69.

Hendrickx M. 1999a. Los camarones Penaeoidea bentónicos (Crustacea: Decapoda: Dendrobranchiata) del Pacífico Mexicano. CONABIO e Instituto de Ciencias del Mar y Limnología, UNAM, México, 149 pp.

Hendrickx M. 1999b. Los camarones pelágicos del Pacífico mexicano (Dendrobranchiata y Caridea). CONABIO e Instituto de Ciencias del Mar y Limnología, UNAM, México, 157 pp.

Hendrickx M. 1999c. Los cangrejos braquiuros (Crustacea: Brachyura: Dromiidae, hasta Leucosiidae) del Pacífico mexicano. CONABIO e Instituto de Ciencias del Mar y Limnología, UNAM, México, 178 pp.

Hendrickx M. 1999d. Los cangrejos braquiuros (Crustacea: Brachyura: Majoidea y Parthenopoidea) del Pacífico mexicano CONABIO e Instituto de Ciencias del Mar y Limnología, UNAM, México, $281 \mathrm{pp}$.

Hyslop EJ. 1980. Stomach contents analysis: A review of methods and their application. J. Fish Biol. 17: 411-429. http://dx.doi.org/10.1111/j.1095-8649.1980.tb02775.x

Karpouzi VS, Stergiou KI. 2003. The relationships between mouth size and shape and body length for 18 species of marine fishes and their trophic implications. J. Fish Biol. 62: 1353-1365. http://dx.doi.org/10.1046/j.1095-8649.2003.00118.x

López-Martínez J, Herrera-Valdivia E, Rodríguez-Romero J, Hernández-Vázquez S. 2010. Peces de la fauna de acompañamiento en la pesca industrial de camarón en el Golfo de California, México. Rev. Biol. Trop. 58: 925-942.

Ludwig J, Reynolds J. 1988. Statistical Ecology: A Primer on Methods and Computing. John Wiley, New York, 337 pp.

Magraña E, Gilberto DA. 2007. Feeding ecology and abundance of two sympatric skates, the shortfin sand skate Psammobatis normani McEachran, and the smallthorn sand skate $P$. rudis Günther (Chondichtyes, Rajidae), in the southwest Atlantic. ICES J. Mar. Sci. 64: 1017-1027. http://dx.doi.org/10.1093/icesjms/fsm078

Márquez-Farías JF. 2007. Reproductive biology of shovelnose guitarfish Rhinobatos productus from the eastern Gulf of California Mexico. Mar. Biol. 151: 1445-1454. http://dx.doi.org/10.1007/s00227-006-0599-3 
Márquez-Farías JF, Blanco-Parra MP. 2006. Las rayas del Golfo de California. In: Arreguín F, Beléndez L, Méndez I, Solana R, Rangel C (eds.), Sustentabilidad y Pesca Responsable en México, Evaluación y Manejo. INAPESCA, SAGARPA, México, pp. 303-322.

McEachran JD, Notabartolo-Di-Sciara G. 1995. Peces batoideos. In: Fischer W, Krupp F, Schneider W, Sommer C, Carpenter K, Niem V (eds.), Guía FAO para la identificación de especies para los fines de la pesca. Pacífico central-oriental. FAO, Rome, Vol. II, pp.754-798.

Navarro-González JA, Bohórquez-Herrera J, Navia AF, CruzEscalona VH. 2012. Diet composition of batoids on the continental shelf off Nayarit and Sinaloa, Mexico. Cienc. Mar. 38: 347-362.

Navia AF, Mejía-Falla PA, Giraldo A. 2007. Feeding ecology of elasmobranch fishes in coastal waters of the Colombian Eastern Tropical Pacific. BMC Ecol. 7: 1-10. http://dx.doi.org/10.1186/1472-6785-7-8

Navia AF, Torres A, Mejía-Falla PA, Giraldo A. 2011. Sexual, ontogenetic, temporal and spatial effects on the diet of Urotrygon rogersi (Elasmobranchii: Myliobatiformes). J. Fish Biol. 78: 1213-1224. http://dx.doi.org/10.1111/j.1095-8649.2011.02931.x

Payán LF, Navia AF, Rubio EA, Mejía-Falla PA. 2011. Biología de la raya guitarra Rhinobatos leucorhynchus (Günther 1867) (Rajiformes: Rhinobatidae) en el Pacífico colombiano. Lat. Am. J. Aquat. Res. 39: 286-296.

http://dx.doi.org/10.3856/vol39-issue2-fulltext-10

Platell ME, Potter IC, Clarke KR. 1998. Resource partitioning by four species of elasmobranchs (Batoidea: Urolophidae) in coastal waters of temperate Australia. Mar. Biol. 131: 719-734. http://dx.doi.org/10.1007/s002270050363

Rinewalt CS, Ebert DA, Cailliet GM. 2007. Food habits of the sandpaper skate, Bathyraja kincaidii (Garman 1908), off central California: Seasonal variation in diet linked to oceanographic conditions. Environ. Biol. Fish. 80: 147-163. http://dx.doi.org/10.1007/s10641-007-9218-5

Ritchie EG, Johnson CN. 2009. Predator interactions, mesopredator release and biodiversity conservation. Ecol. Lett. 12: 982-998. http://dx.doi.org/10.1111/j.1461-0248.2009.01347.x

Robinson HJ, Cailliet GM, Ebert DA. 2007. Food habits of the longnose skate, Raja rhina (Jordan and Gilbert 1880), in central California waters. Environ. Biol. Fish. 80: 165-179. http://dx.doi.org/10.1007/s10641-007-9222-9
Rogers PJ, Huveneers C, Page B, Hamer DJ, Goldworthy SD, Mitchell JG, Seuront L. 2012. A quantitative comparison of the diet of sympatric pelagic sharks in gulf and shelf ecosystems off southern Australia. ICES J. Mar. Sci. 69: 1382-1393 http://dx.doi.org/10.1093/icesjms/fss100

San Martin MJ, Braccini JM, Tamini LL, Chiaramonte GE, Perez JE. 2007. Temporal and sexual effects in the feeding ecology of the marbled sand skate Psammobatis bergi Marini, 1932. Mar. Biol. 151: 505-513. http://dx.doi.org/10.1007/s00227-006-0499-6

Talent LG. 1982. Food habits of the gray smoothhound Mustelus californicus, the brown smoothhound Mustelus henlei, the shovelnose guitarfish Rhinobatos productus, and the bat ray Myliobatis californica, in Elkhorn Slough, California. Calif. Fish Game 68: 224-234.

Treolar MA, Laurenson LJB, Stevens JD. 2007. Dietary comparisons of six skate species (Rajidae) in south-eastern Australian waters. Environ. Biol. Fish. 80: 181-196. http://dx.doi.org/10.1007/s10641-007-9233-6

Valadez-González C. 2000. Hábitos alimentarios de las rayas (Chondrichthyes: Rajiformes) capturadas en la plataforma continental de Jalisco y Colima, México. MSc thesis, Universidad de Colima, México, 114 pp.

Valadez-González C. 2007. Distribución, abundancia y alimentación de rayas bentónicas de la costa de Jalisco y Colima, México. $\mathrm{PhD}$ thesis, CICIMAR-IPN, La Paz, México, $137 \mathrm{pp}$.

Valadez-González C, Saucedo-Lozano M, Raymundo-Huizar AR. 2006. Aspectos tróficos de las rayas bentónicas de Jalisco y Colima. In: Jiménez-Quiroz MC, Espino-Barr E (eds.), Los Recursos Pesqueros y Acuícolas de Jalisco, Colima y Michoacán. SAGARPA, Instituto Nacional de la Pesca, México, pp. 235-248.

Wetherbee B, Cortés E, Bizzarro JJ. 2012. Food consumption and feedings habits. In: Carrier JC, Musick JA, Heithaus MR (eds.), Biology of Sharks and their Relatives. 2nd ed. CRC Press, Boca Raton, pp. 239-264.

White WT, Platell ME, Potter IC. 2004. Comparisons between the diets of four abundant species of elasmobranchs in a subtropical embayment: Implications for resource partitioning. Mar. Biol. 144: 439-448. http://dx.doi.org/10.1007/s00227-003-1218-1

Wilga C, Motta P. 1998. Feeding mechanism of the Atlantic guitarfish Rhinobatos lentiginosus: Modulation of kinematic and motor activity. J. Exp. Biol. 201: 3167-3184.

Winemiller K, Pianka E. 1990. Organization in natural assemblages of desert lizards and tropical fishes. Ecol. Monogr. 60: 27-55.

Received September 2012, received in revised form December 2012, accepted January 2013. 